UDK 781.61 Srebotnjak A.

Niall O'Loughlin

Loughborough

\author{
ALOJZ SREBOTNJAK'S USE OF TWELVE-NOTE \\ TECHNIQUES
}

One of the only Slovenian composers to make consistent and thorough use of twelve-note technique has been Alojz Srebotnjak. After composing during the $1950 \mathrm{~s}$ a number of works that used a broadly traditional approach with modernisms such as added 'wrong' notes, he went to London in 1959 to study with Peter Racine Fricker. Srebotnjak's compositions from this time have used a moderately strict note-serialism. Although this has usually involved twelve-note rows, in one instance (the Harp Concerto) he used a row consisting of only eight notes. The style of these works written since 1960 has been varied, with an almost Webernian terseness in the Six Pieces for bassoon and piano, a lighthearted and regular rhythmic structure in the Serenata for wind trio and the involved orchestral textures of Antifona and parts of the Harp Concerto that recall the orchestral style of Arnold Schoenberg.

Invenzione variata for piano of 1961 is a sequence of eleven free variations around a twelve-note row. The work is not a set of variations on a theme in the traditional sense, but rather contrasting sections which relate to each other in terms of the note-row. The twelve-note row itself is treated with a great deal of freedom. Srebotnjak frequently used the notes simultaneously, which inevitably disguises some of the melodic character of the row. Further, unlike Švara in his Concerto grosso dodecaphono and Tri etude, he usually introduced inversions, retroversions and transpositions of the row at an early stage. It is sometimes difficult to establish the exact order of some of the note-rows used. For example, because the opening of Invenzione variata, with its three three-note chords (excluding the octave $C$ in the bass) in the first three bars, does not allow us to determine the exact order (Ex. 1a), this must be established by comparison with a later passage (Ex. 1b), which then gives the numbered order in Ex. 1a. One example of a permutation with its inversion is given in Ex. 1c, in which the original order of notes five and six is reversed. Note, also, the mirroring of the shapes of the first half in the second half of the same example. Mirror forms and symmetrical patterns were later to feature more prominently in the Six Pieces for bassoon and piano. In Invenzione variata they occur but are less frequent. The most important aspect concerns the individual sections. Sections A, B, C, F and K are all fifteen bars long and $J$ (an unbarred cadenza) is equivalent in length. The last section of the work $(K)$ is the exact reverse of $A$, and the two halves of $H$ are exactly the same as the two halves of D, but in reverse order (the actual order of the notes is not reversed). 
The Serenata for flute, clarinet and bassoon also of 1961 is a light and diverting work of six short movements. The rhythms are straightforward with regular barring and only a few tempo and metre changes within each movement. There is a fairly strict use of the chosen twelve-note row throughout the work and there is a continuation of the use of neat symmetrical patterns. As is often the case in the music of Srebotnjak, the exact order of the note-row is not immediately apparent because of the use of chords (Ex. 2b). This row can be discovered from a later passage played unaccompanied by the bassoon (Ex. 2a). The first two bars of Ex. $2 b$ present the row in its original form as four chords. In the third bar the row is divided into two hexachords and played in inverted form in overlapping parts by the flute and clarinet. The process is continued in bars 4 and 5 with the original form reversed as four three-note chords and then in bar 6 with the inverted hexachords reversed and played in overlapping lines by the clarinet and bassoon. Thus in the first four bars the composer has given us, in very compressed form, the four versions of the basic untransposed row. ${ }^{1}$ The next few bars give a new development, with bassoon and clarinet sharing one row form while the flute plays the retrograde independently. There is some reordering of the notes of the row from time to time, e.g. at the beginning of the third movement (Ex. 2c). Note also the palindromes in bars 1-2 and 4-5 in Ex. 2b.

Monologi ('Monologues') from the following year, 1962, for strings, timpani and three wind instruments (one in each of the movements, flute, oboe and horn respectively) is an intense and brooding work completely different in style from the Serenata for wind. The work opens with a dissipated version of the row with numerous repetitions and notes 11 and 12 coming before note 10 (Ex. 3a). Any confusion is removed with the immediate repetition of the original form of the row by the solo oboe and by its inversion (Ex. 3b). Repetition of notes within the row (Ex. 3a) is very common in the work, especially on the timpani. The wind parts normally use note-rows independently of the rest of the orchestra, a feature that was later to be extended in the Harp Concerto to include two separate note-rows.

The formal plans of the movements of Monologi are quite simple, as in the Serenata. The first two are ternary derivatives and the third a set of variations. Many of the works that now followed broke new ground from these traditional plans, very strikingly in the case of the terse Six Pieces for bassoon and piano that date from 1963. Their small scale disguises a compression of thought and complexity of form that is not immediately apparent. The twelve-note technique that must have been now almost second nature to the composer is used harmonically and melodically, with the bassoon and piano parts normally independent of each other except in passages which avoid doublings. Repeated notes, either as part of chords themselves repeated complete or as individual repetitions in a melodic line, are frequent. The pieces employ a mixture of solo melodic lines, with (Ex. 4b) or without accompaniments (Ex. 4a), or as melodic lines contrapuntally combined (Ex. 4c).

There is a strong move away from traditional forms. In the fourth and fifth pieces there is some concession to ternary form. In the fourth the rhythm of the opening phrases is recapitulated with considerable alteration of the notes. In the fifth, there is a reprise of the first two bars only, with a coda recalling the middle section. The third piece is completely palindromic in plan, while the sixth, in a fragmentary fashion typical of the whole work, juxtaposes in an uncomfortable succession material directly

1 Some apparent departures from the note-row in the printed score are misprints, which have been confirmed by the composer. Ex. 2 gives the correct readings. 
derived from each of the previous pieces. The row is built as four groups of three notes with a semitone in each group, while the second half of the row is an almost exact inversion of the first half.

Srebotnjak did not use this terse style in his next work, Microsongs for voice and thirteen instruments. Alghouth the composer used only solo strings (violin, viola, cello and double bass), the work is in essence an orchestral song-cycle, settings of brief texts by Slovenian poets or of translations into Slovene. Srebotnjak did not attempt to consolidate the purely musical achievement of the bassoon pieces, but rather to create short atmospheric settings in which the words to some extent dictated the style and form. The songs are linked by the use of a single note-row.

The mood of the first song, Kitajska modrost ('Chinese wisdom'), is emphasised by the heavy bass register of the chord formed from the first four notes of the row, sustained against the voice which chants the eight remaining notes (Ex. 5a). In the remainder of the song the voice part is independent of the ostinato-like accompaniments, a feature also found in Harlekin, the second song. The lethargic atmosphere of the third song, Dolgčas ('Boredom'), is magically caught. The slow-moving melody of the bass clarinet which opens the song is doubled by string glissandos and trills. This simple statement of the note-row is followed by another from the singer, who yawns through it with glissandos with the hand in front of the mouth and with a few notes of Sprechgesang. This catches the atmosphere of the 'profound' utterance, 'ves svet je en sam' ('the world is all the same') perfectly. Collage starts with a full harmonic statement of the row as a noisy and violent curtain-raiser to the singer's strictures on the motorist. This use of all the twelve notes in one chord is found extensively in the orchestral work Antifona. De profundis, to words by Alojz Gradnik has a much more subtle use of the row. In the opening (Ex. 5b), the row is presented melodically by the harp and clarinet, with the voice then taking it over in the same form on the same notes but in different octaves. At the same time the clarinet plays an inverted form pitched a fourth higher which carefully avoids any doubling. In the rest of the song the singer takes over the inverted form and then returns to the original form to the counterpoint of the clarinet's inversion. The harp provides harmonic statements of the row in chords containing up to six notes. The interlude Utrinek (without voice) introduces a new element, the building up of a chord one note at a time, also used in the ninth song Megla ('Mist'). In Megla the row of the vocal line is independent of that of the chords.

Collage // involves some brilliant verbal juggling. Srebotnjak took a number of words from the orthography of Slovene, i.e. es, esej, esenca, esesovec, etc., ending in mid-air, so to speak, on 'Eskim-'. Here the instrumental group cuts in with a dense texture in which the percussionist plays loud strokes on the tam-tam while the other twelve players each improvise for four bars on a group of four notes. These are arranged with numerous doublings and not in any grouping that would avoid having the same notes in different parts. Each player, however, has a different group of four notes on which to improvise. This interruption is followed by the words from the singer: kontra, kontra-admiral, kontrabant, kontrabas. Not surprisingly, the double bass enters now. At the same time the singer completes the word broken off earlier, 'Eskim-', with 'o', which becomes the first syllable of 'Au revoir', the singer's farewell, which is cut off abruptly by a repetition of the earlier improvised passage.

The Microsongs are short but effective pieces which use some interesting and varied twelve-note applications. They stand somewhat apart from Srebotnjak's development, which includes very few vocal works. The composer seized the opportu- 
nity of creating atmospheric miniatures without abandoning his twelve-note technique. The texts did lead him toward certain developments, notably the use of free improvisation around a limited number of notes, but Microsongs show none of the symphonic thinking to be found in Antifona and the Harp Concerto.

The orchestral work Antifona also dates from 1964. Although its duration, eleven minutes, is about the same as that of Microsongs, it is a completely different type of work. While Microsongs are short, atmospheric settings, Antifona is a highlyunified single-movement edifice. It is planned around two basic tempos, Adagio $d=52$ and an Allegro $d=120$, with a few minor fluctuations. As the title suggests, there is considerable use of antiphony, especially between groups of instruments (see Ex. 6a and 6b). Unlike Microsongs, the work uses a certain amount of thematic crossreferencing, but Srebotnjak only occasionally used a well defined statement of his note-row (Ex. 6c). It more often appears contrapuntally (see the row and its inversion in the cello and double bass parts of Ex. $6 a$ and in Ex. 6d in which the trombone and violin share the inversion of the viola's statement). As in Microsongs there are numerous appearances of chords containing all twelve notes (see Ex. 6b).

The use of a full twelve-note row presents no insoluble problems for most orchestral instruments. The diatonic harp, however, has by its very nature certain difficulties in dealing with highly chromatic music. Ivo Petrić is a composer who has successfully mastered the obvious limitations in a modern idiom that uses all twelve notes freely. Srebotnjak, on the other hand, in writing his Harp Concerto of 1970, produced a novel solution to the problem: the harp uses an eight-note row, while the orchestra's music is derived from a twelve-note row. By careful melodic and harmonic manipulation the composer avoided any doubling of notes between the note-rows. These two note-rows (harp: B flat, C flat, E, D, F, G, A flat, D flat; orchestra: F, F sharp, C, B, D sharp, G, A, E, D, D flat, A flat, B flat) have intervals in common (minor and major seconds and perfect fourths and fifths), but other intervals exclusive to each (harp: minor third; orchestra: major third and augmented fourth). The character of each row is thus clear in melodic form (Ex. 7a, harp; Ex 7b, orchestra). As in Antifona, however, the straightforward melodic form is uncommon, as Srebotnjak favoured the use of the row in which the notes are shared between instruments in the form of melody and accompaniment, as at the beginning of the second movement (Ex. 8). Here he uses the retrograde form of the orchestral row (see original form above) transposed up a major third. The first two notes are sustained on horns and violas throughout the passage. The next three notes are repeated numerous times as a metrical canon between the three trumpets. The remaining seven notes constitute the main melodic interest of the passage, an assumption confirmed by the strengthening of the line not only by the second violins but also the flutes, oboes and clarinets. In order to make the line suitably long, Srebotnjak repeated notes within this group without using any of the notes already being played by the violas, horns or trumpets.

As in the Microsongs the harmonic nature of the music is carefully calculated. This was clear in Ex. 8 where Srebotnjak reserved specific notes of the row for certain instruments. This harmonic awareness is also apparent in the harp solo at the beginning of the first movement (Ex. 9a), in which the simultaneous playing of adjacent notes of the row is changed at each appearance. Chords consisting of all twelve notes of the orchestral note-row are frequently used, either sounding all together at once or built up note by note. An effective use of a succession of six-note chords is found in the brass and string chorale found near the end of the second movement (Ex. 9b). Two six-note chords alternate with different spacings. The actual notes chosen (I: A, 
B flat, C, E, E flat, G; II: A flat, B, D flat, D, F, G flat) are reconcilable with the original note-row only if the permutation of the row involving the exchange of notes six and seven is assumed. By transposing the original note-row up a major third from the first note of $F$ to $A$, the sixth and seventh notes would be $B$ and $C$ respectively, but in fact they are the other way round. Some confirmation is given to this analysis in the succession of harp chords (Ex. 9c) which echoes the chorale of Ex. 9b. The harp's eightnote row is also in its original form and also transposed up a major third. By using only three-note chords in the harp passage, Srebotnjak was able to introduce more complex permutations than in Ex. 9a and to avoid the rigid alternation of the sixnote groups found in Ex. 9b.

Although Srebotnjak advanced in one direction by using two separate note-rows, his approach to form was somewhat less adventurous than in the symphonic movement Antifona. The Harp Concerto is cast in two movements only, a theme and variations and an Allegro freely based on sonata form. The first movement's theme provides the serial genesis of the variations, both melodically and harmonically. In the second movement the first and second 'subjects' are presented by the orchestra and harp respectively, replacing the traditional key contrast by one of note-rows. The reconciliation between the two note-rows is not attempted in any form of recapitulation, but in the chorale alternations noted in Exx. 9b-c, which constitute the major part of the extended coda which ends the movement and, of course, the whole work.

Srebotnjak's return to miniature forms in the chamber work Dnevnik ('Diary') for violin, cello and piano of 1972 shows a tightening of the overall structure. There is no use of the ternary forms that were used in the variation first movement of the Harp Concerto, nor is there any of the sudden change of atmosphere that was found in Microsongs. Dnevnik plays for nearly fifteen minutes without a break, although it is written in a number of contrasting sections. The framework of the piece is provided by a Prelude, Interlude and a Postlude. Between the first two there are five short 'events', and between the second and third another four similar 'events'. The substantial Interlude (nearly ten pages in the score) and the shorter Prelude and Postlude (four pages each) are in fast tempos, i.e. Allegro molto, Allegro and Agitato respectively. The progression of tempos used for the 'events' is broadly similar in both groups (slow, faster, fast, moderate), although there is no strict symmetry between the five 'events' of the first group and the four of the second group. As each of the 'events' occupies about two pages in the score, these groups of 'events' can be seen to balance the Interlude, which is about the same length.

The composer's use of twelve-note technique shows some similarity to that used in previous works, but also some new developments. The original form of the row is found in Event I (Ex. 10a), while the clearest unambiguous statement of the work's twelve-note row appears as the cello 'ground bass' in Event $V$ (Ex. 10b). The latter appears inverted and reversed. The row itself shows no obvious symmetry, having some preponderance of particular intervals (three each of minor seconds and minor thirds). While much of the work uses the note-row fairly strictly, Srebotnjak takes a number of liberties with it in Event II (Ex. 11). There are also examples in Events IV and $V$. In the latter, two forms of the row a perfect fifth apart are used. The reordering of some notes of the row is made to avoid doubling of notes. A more involved development appears in the Prelude in which the string instruments have freely coordinated six-note ostinatos with four notes in common. These ostinatos are suddenly stopped by the pianist who interrupts them with eight notes played simultaneously, the remaining four notes following immediately as a chord. This typifies the composer's 
treatment in the Prelude of the row as two semiindependent segments, normally of eight and four notes.

Although much in Dnevnik avoids neat symmetries, there are some intriguing rhythmic patterns in Event VIII. Working in quaver beats Srebotnjak uses bar-lengths according to the following patterns of beats, 1234543216, and then in reverse order. The whole group (in both directions) is used a total of three times, but Srebotnjak does not repeat the last bar-length (6 or 1 ) when changing direction. The rhythmic groupings are very nearly palindromic, containing only a few notes different in the reverse forms. The bar-groupings are connected with the use of the row. All the bars in $1 / 8$ time begin statements of the row with a single quaver in the extreme high or low register (except for the very last bar). The three 6/8 bars are the only ones with fournote chords, three-note chords normally being used. Symmetries of melodic contour are not strict despite the regular patterns of bar-lengths.

In his twelve-note works Alojz Srebotnjak has made a determined effort to master the technique in a form which shows little debt to tonal language. His first twelvenote works, such as the Invenzione variata for piano, take Schoenberg's basic technique as their starting point. Later works such as the Six Pieces for bassoon and piano show the influence of Webern in their use of mirror forms and palindromes of pitch and rhythm. The Harp Concerto has a new departure in its use of two different noterows, an indication of the composer's desire to develop his technique. His achievement, though not extensive, is nevertheless impressive. It is surprising that not other composers in Slovenia have followed his lead in adopting twelve-note technique, except in passing. Instead, his contemporaries have found much more of interest in the methods of contemporary Polish composers.

\section{MUSIC EXAMPLES}

Ex. 1 (DSS 131, a) p.3 b.1-4; b) p.3 b.16-18; c) p.9 b.22 - p.10 b.4)

a)

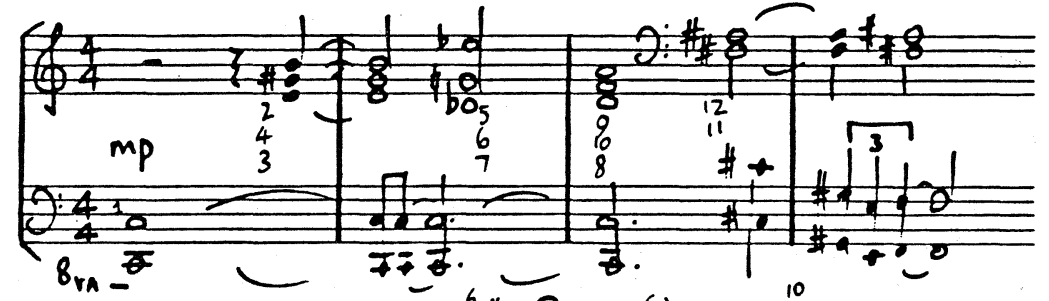

b)

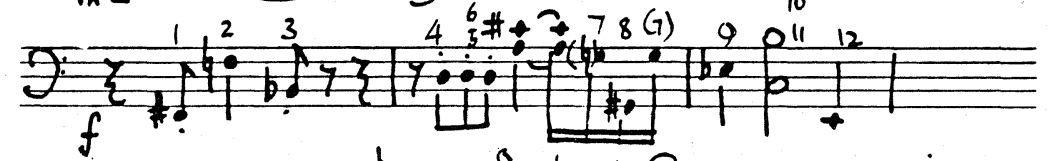

c)

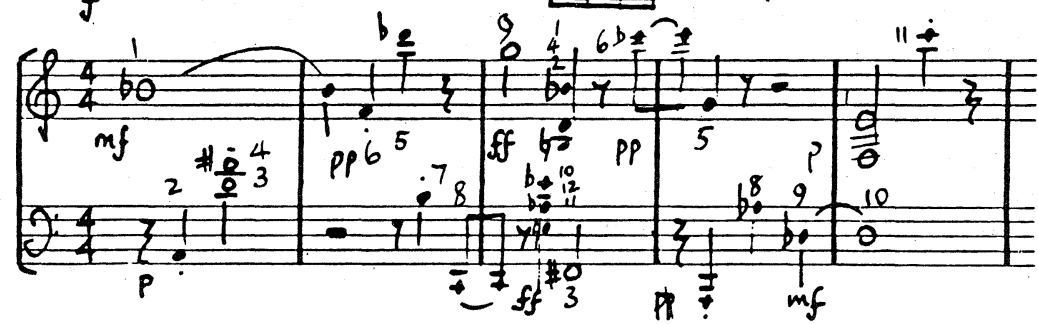


Ex. 2 (DSS 255, a) p.4 b.4-8; b) p. 2 b.1-6; c) p.7 b.1-5)
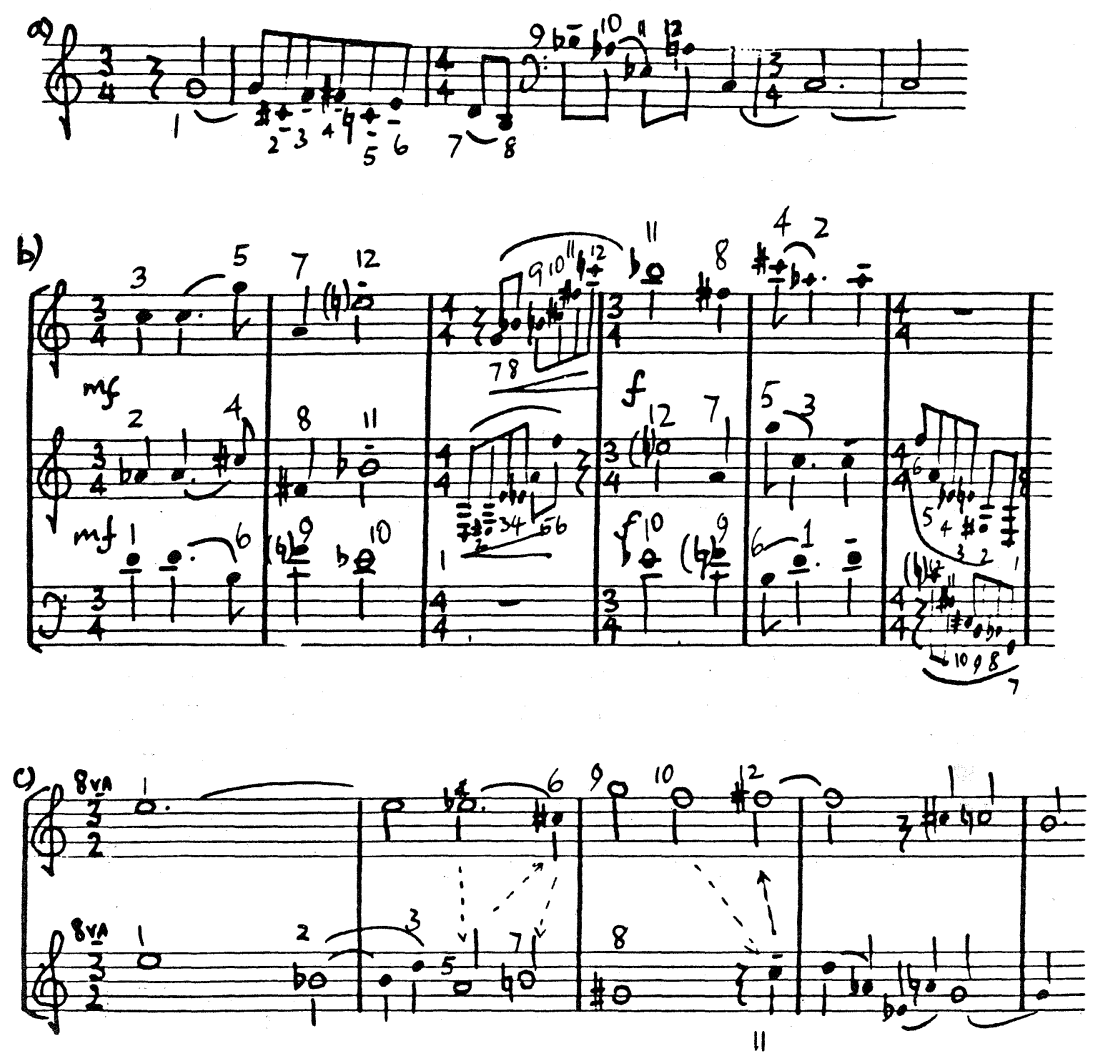

Ex. 3 (DSS 150 , a) p. 3 b. $1-4$; b) p. 3 b. 4 - p. 4 b.4)

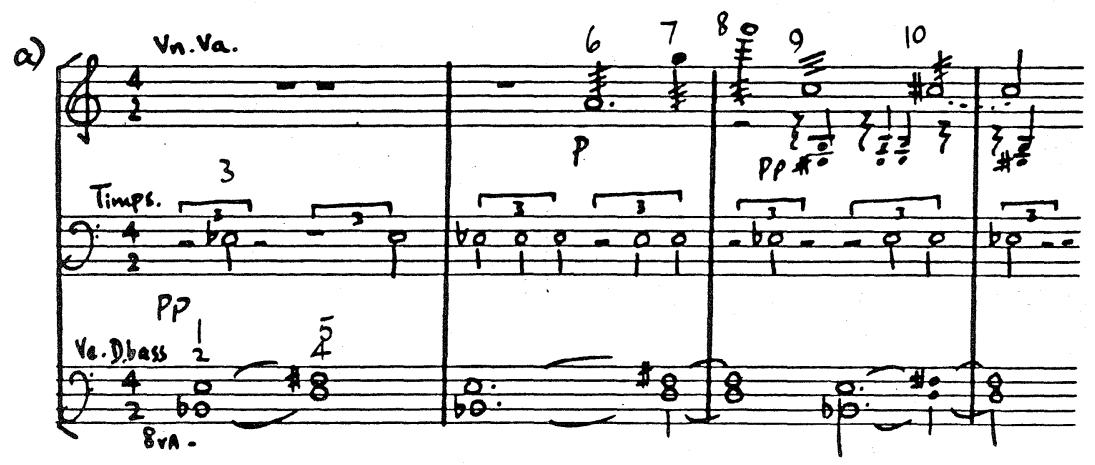




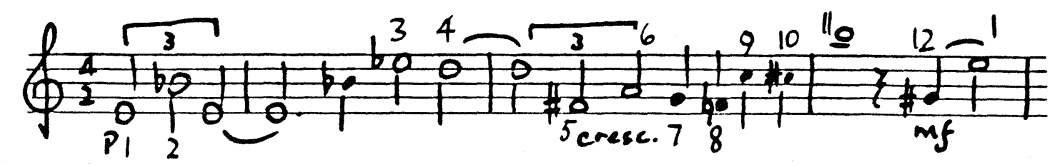

b)

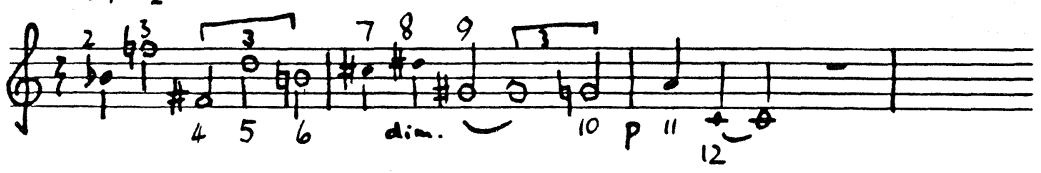

Ex. 4 (GS 2934, a) p.6 b.6-10; b) p.7 b.1-6; c) p.2 b.1-2)
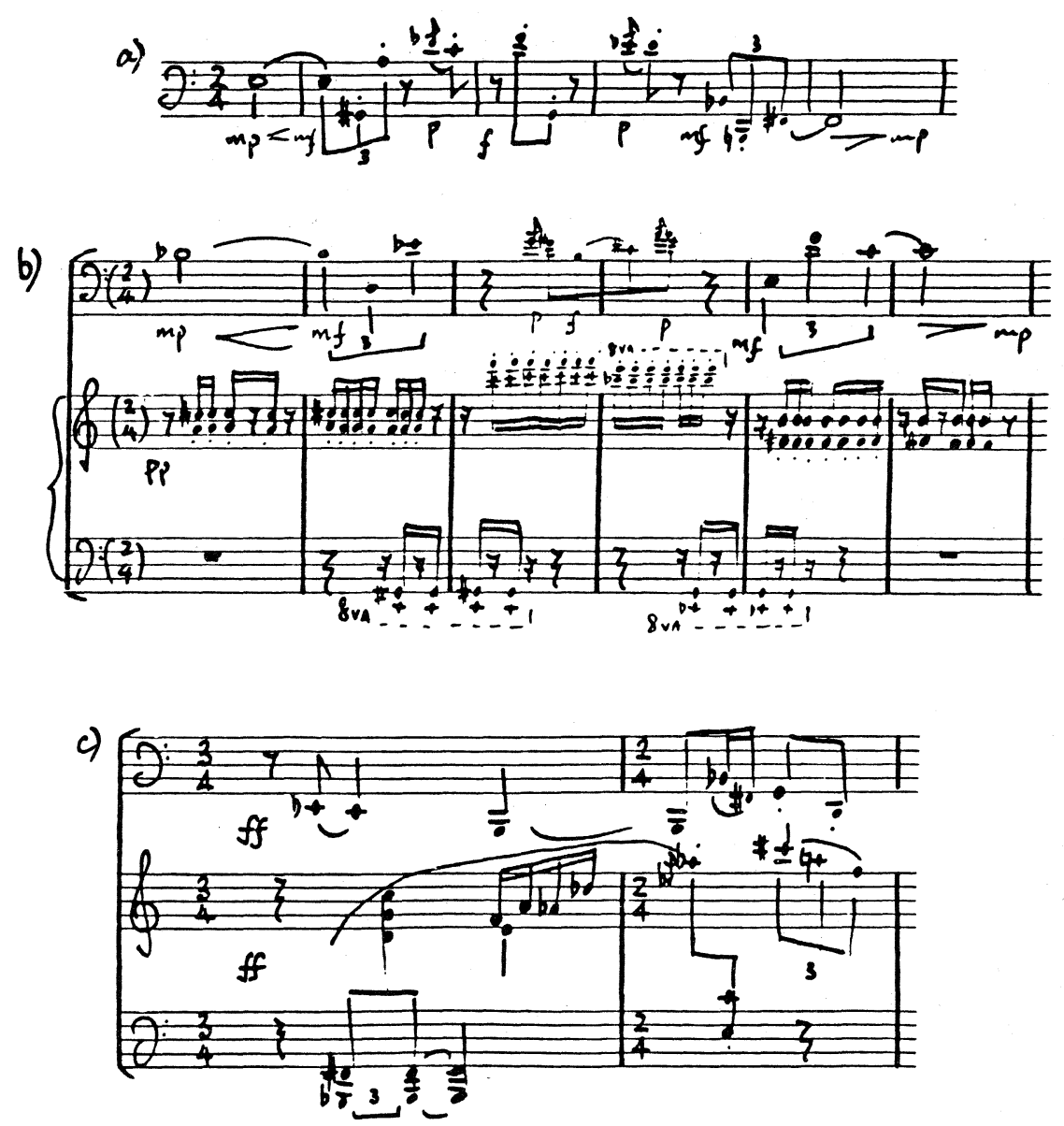
Ex. 5 (DSS 285 , a) p.2 b.1-3; b) p.18 b.1-5)

a)

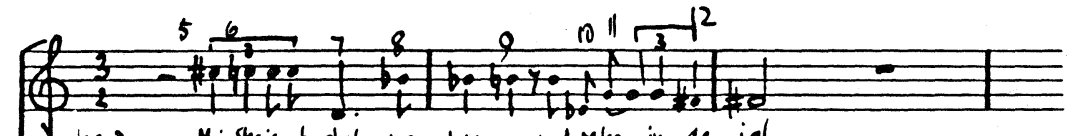
$\operatorname{mp}_{3}$ Moj-stejeob-stal na bregu nad reko in ae-jal.

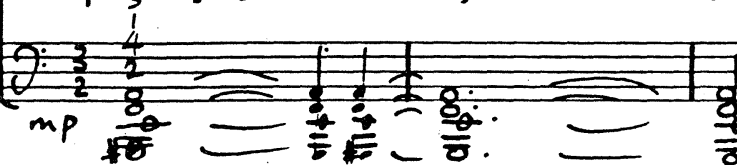

b)

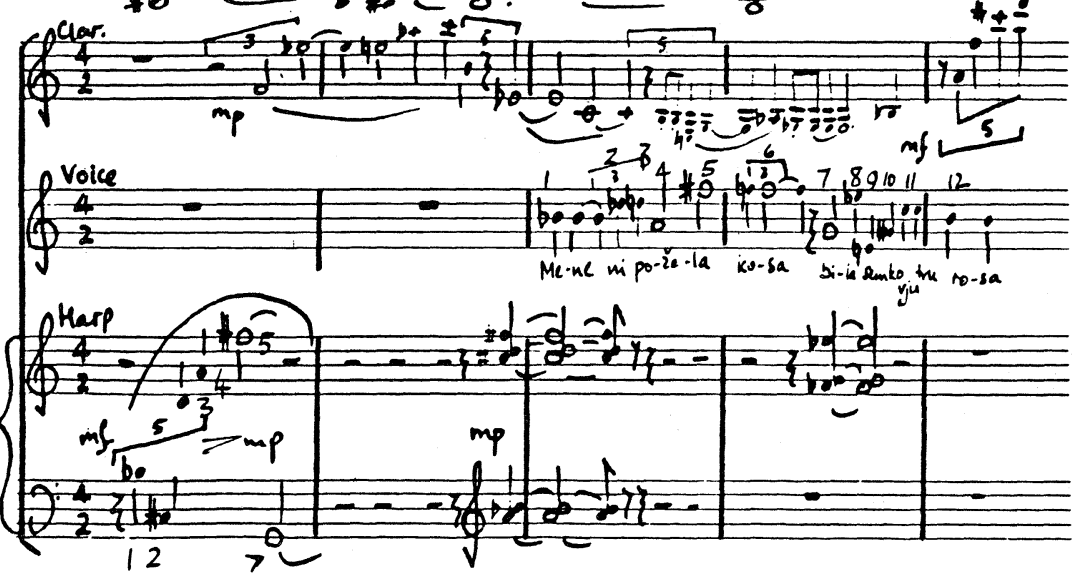

Ex. 6 (DSS 211, a) p. 3 b. 1 - p. 4 b. 2; b) p. 13 b. $1-2$; c) p. 7 b. 1 - p.8 b.2; d) p.37 b.2 p.38 b.2)

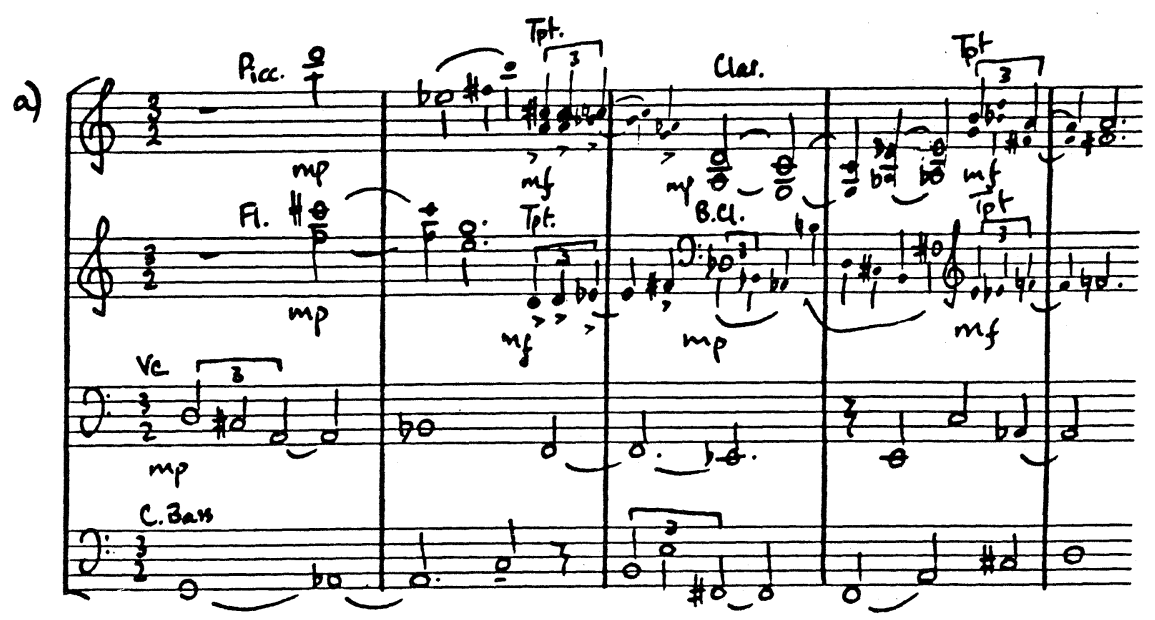


b)

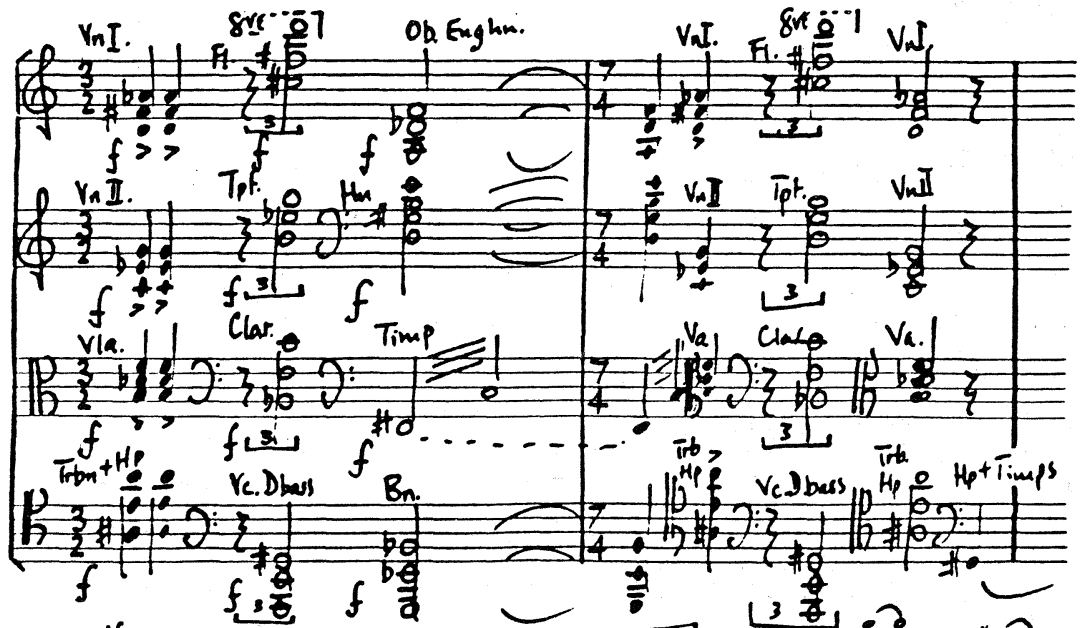

c)

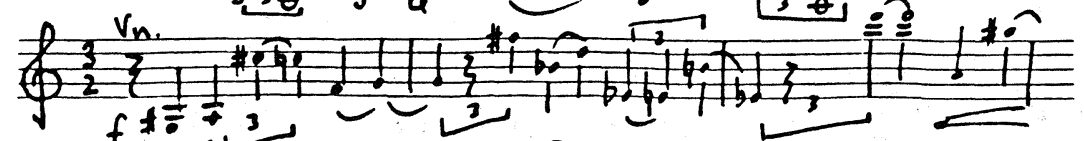
10

d)

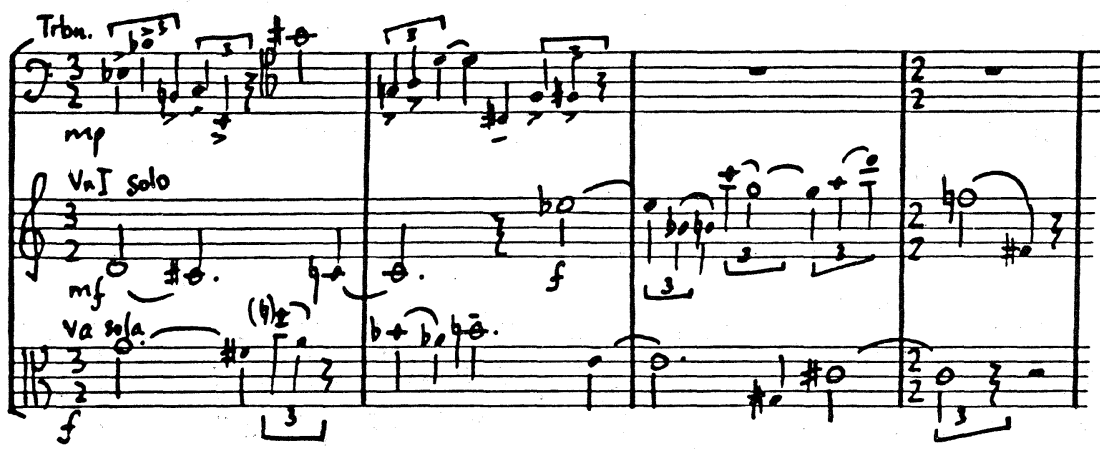

Ex. 7 (GS 1972, a) p.20 b.2-3; b) p.46 b.3 - p.47 b.1)

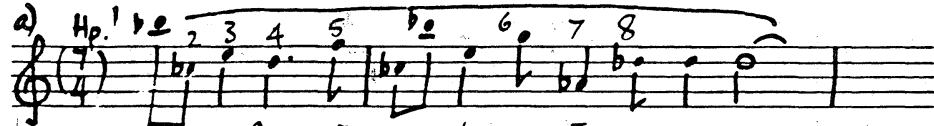

$\frac{f 5}{3}$ 


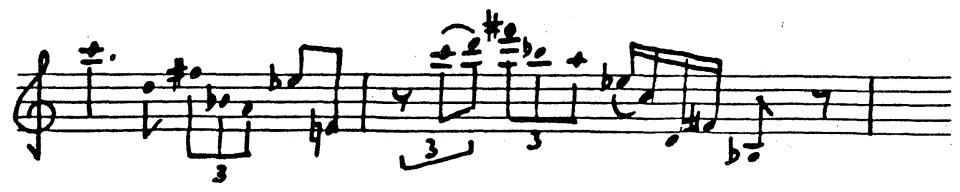

Ex. 8 (GS 1972, p.25 b.1-3)

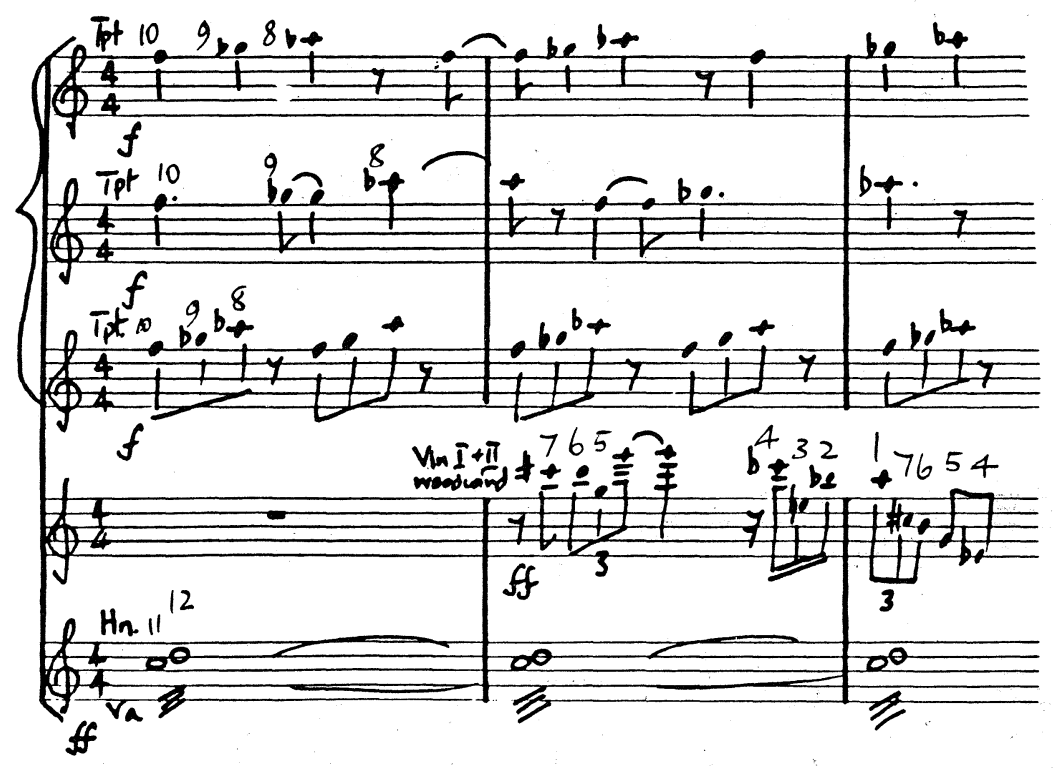

Ex. 9 (GS 1972, a) p.2 b. 2 - p.3 b. 1; b) p.59 b.5 - p.60 b.1; c) p.60 b. 3-5)

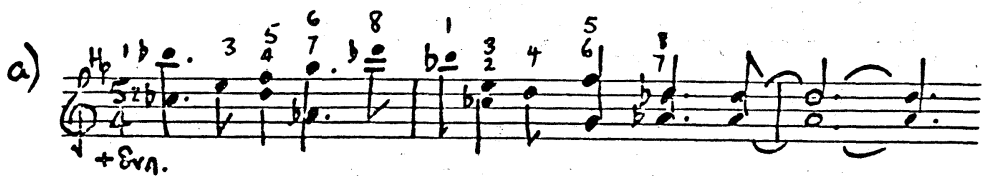

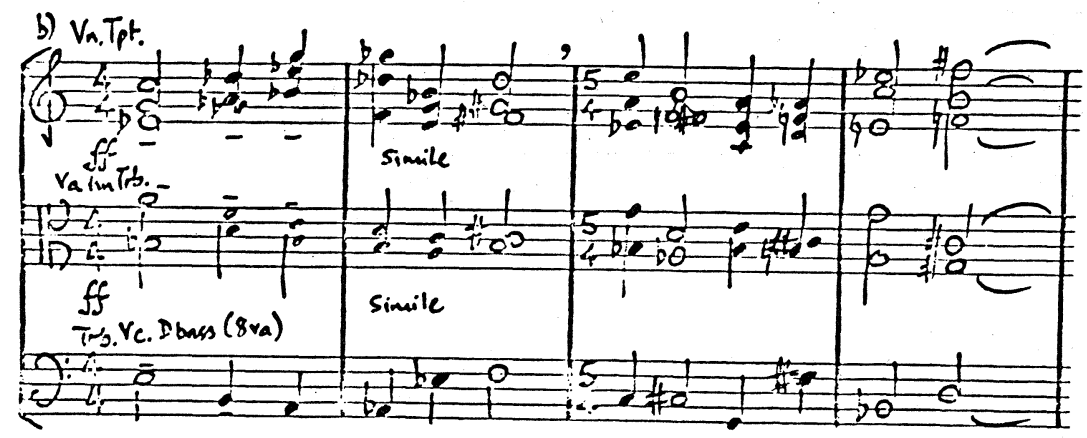




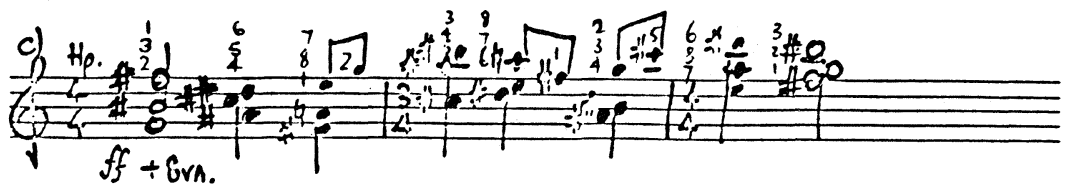

Ex. 10 (DSS 558, a) p.4 b.7-9; b) p.12 b.1-2; c) p.6 b.1-4)
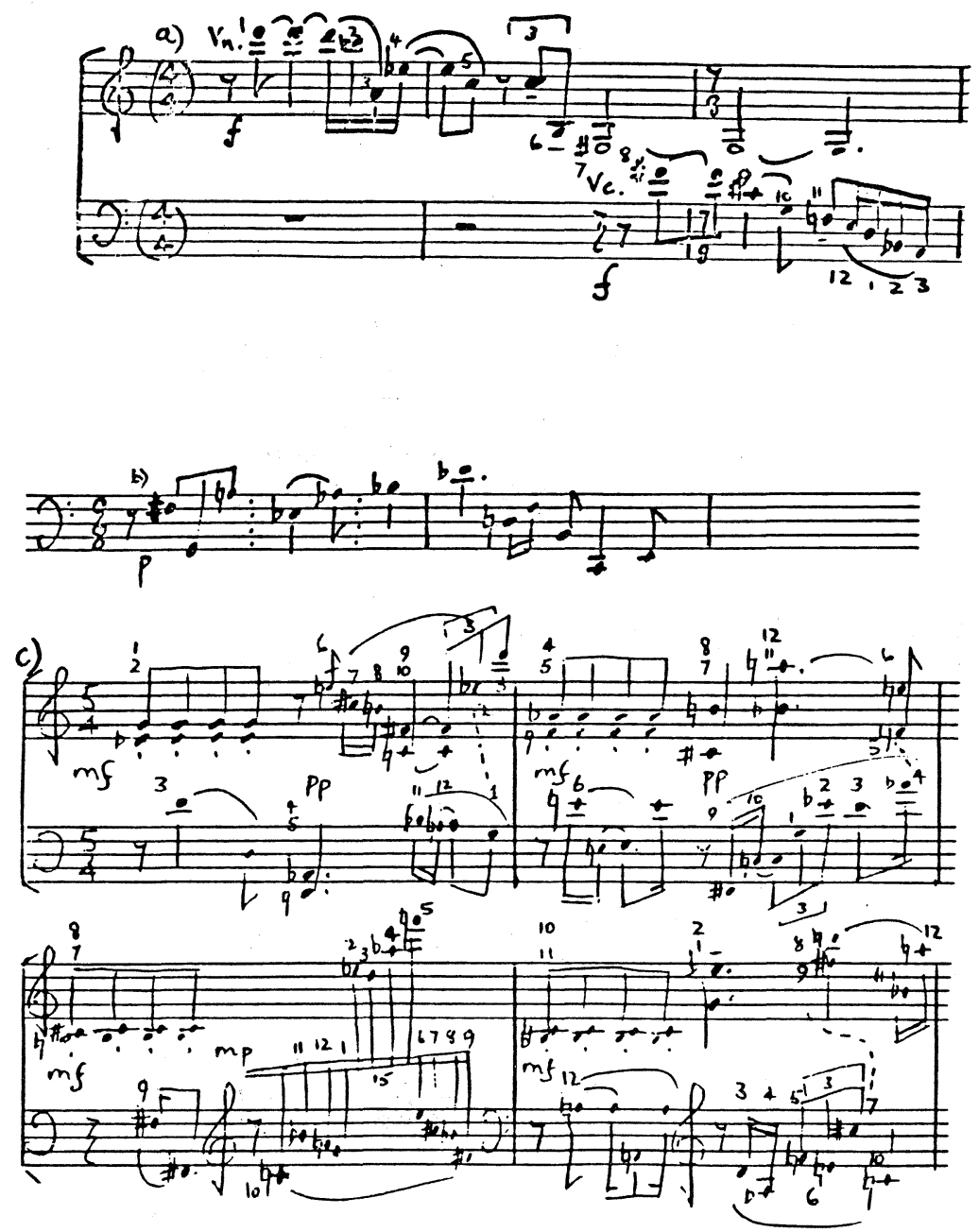


\section{POVZETEK}

Alojz Srebotnjak, ki je leta 1959 v Londonu študiral pri Petru Racinu Frickerju, je eden izmed redkih slovenskih skladateljev, ki uporablja dvanajsttonske tehnike, in to z zmerno strogostjo na različne načine. Z zgodnjo Invenzione variata za klavir je ustvaril variacijsko sosledje, $v$ katerem razmeroma svobodno obravnava izbrano serijo, pri čemer so opazni tudi nekateri zrcalni postopki. Serenata za pihalni trio je lahkotno neoklasicistično delo s sočasno in "premetano" uporabo tonov. Monologi iz leta 1963 prestavljajo te in take prijeme na področje orkestralnega zvoka, v katerem pihalni solisti izvajajo tonske serije neodvisno od godal. Šest skladb za fagot in klavir odseva kompozicijsko zapletenost, a obenem tudi strnjeno kratkost. Prisotna je precejšnja uporaba zrcalnih oblik in palindromskih prijemov, tako da šesta kalejdoskopsko rekapitulira gradivo predhodnih petih skladb. Microsongs, nekakšne "atmosferne" miniature, bleščeče izrabljajo besedno-pojmovne in glasbene dvoumnosti. Skladatelj vključuje tudi improvizacijo na omejenem številu tonov izhodiščne serije. Antifona je enostavčna kompozicija z dvema osnovnima tempoma. Uporaba serije je često kontrapunkts$k a$, včasih pa tudi $v$ dvanajsttonskih vertikalnih sklopih. $V$ Koncertu za harfo in orkester Srebotnjak zastavi dve seriji, iz osmih tonov za diatonsko harfo in dvanajsttonsko za orkester. Seriji sta umetelno izbrani, tako da med njima ne prihaja do podvajanja. Čeprav je skladba serijalno zahtevna, pa je sicer oblikovno jasna: gre za temo z variacijami in za svobodni sonatni Allegro. Zadnje delo, ki ga kaže upoštevati, je Dnevnik za violino, violončelo in klavir iz leta 1972. Sestavlja ga več kratkih delov, uokvirjenih s tremi obsežnimi odstavki - Preludijem, Interludijem in Postludijem, med katere je interpoliranih pet oziroma štirje "dogodki", v katerih skladatelj uporablja raznovrstne palindromske tehnike. - Srebotnjakovi dosežki v izrabi dvanajsttonskih tehnik so upoštevanja vredni, saj je z njimi ustvaril prepričljiv corpus kompozicij, pri čemer je zanimivo, da noben drugi slovenski skladatelj - razen občasno - ni uporabil dvanajsttonske tehnike. 